\title{
Mathematical critical thinking and resiliency: Experiment of grade-7 students using scientific approah
}

\author{
Euis Eti Rohaeti *, Dadang Koswara \\ Institut Keguruan dan Ilmu Pendidikan (IKIP) Siliwangi. \\ Jalan Terusan Jenderal Sudirman, Baros, Cimahi Tengah, Kota Cimahi, Jawa Barat, 40526, Indonesia \\ * Corresponding Author. E-mail: e2rht@ stkipsiliwangi.ac.id \\ Received: 11 December 2017; Revised: 23 April 2018; Accepted: 31 December 2018
}

\begin{abstract}
The purpose of this study was to describe the role of scientific approach on students' mathematical critical thinking and resiliency. This study wass a pre test-post test experimental control group design and involves 66 seventh grade students as sample. Data collection was conducted by a mathematical critical thinking test, a mathematical resiliency questionnaire, and a perception on scientific approach questionnaire. Data analysis was conducted using descriptive and inferential analysis. The study found that on mathematical critical thinking ability, students getting treatment by scientific approach attained better than students taught by conventional teaching, but both groups were still at low level. On mathematical resiliency, there was no different between students on both teaching approaches, and those groups were at medium level. The other findings, there was no association between mathematical critical thinking ability and mathematical resiliency, and students performed high perception toward scientific approach.
\end{abstract}

Keywords: mathematical critical thinking, mathematical resiliency, scientific approach

How to Cite: Rohaeti, E., \& Koswara, D. (2018). Mathematical critical thinking and resiliency: Experiment of grade-7 students using scientific approah. Jurnal Riset Pendidikan Matematika, 5(2), 223-232. doi:https://doi.org/10.21831/jrpm.v5i2.17322

Permalink/DOI: https://doi.org/10.21831/jrpm.v5i2.17322

\section{INTRODUCTION}

Mathematical critical thinking ability and mathematical resiliency are two essential mathematics learning outcomes should be improved on students high school. That statement is in line with the goals of mathematics teaching and some experts' conceptions among other are as follow. First, mathematical critical thinking ability and mathematical resiliency are included on the goal of mathematics teaching such as: (a) to posess logical, critical, creative, innovative thinking, and self-learning abilities, and to demonstrate critical, creative, accurate, objective, opened thinking, self-confidence, curious, interest, persevere, persistent attitudes; (b) to appreciate the beauty and the usage of mathematics in daily life. Second, the need of possessing mathematical critical thinking by high school students is in line with an expression ".. in the minds of student thinking critically, mathematical content is transformed into mathematical thinking" (Lunenburg, 2011). Third, the importance of having mathematical critical thinking by student is also in line with Peter's expression as well, namely "student who are able to think critically are able to solve problem effectively" (Peter, 2012). Fourth, besides that, Johnson (Pertiwi, 2011) proposes that a critical thinker tends to behave carefully in taking decision, to confess foolishness fastly, to get new information eagerly, to be patient in investigating a proof, to be tolerant on new viewpoint, and to confess the better viewpoint of other people. Those critical attitudes are needed by students during teaching-learning process.

Some writers explain the term of critical thinking differently, but they include similar meaning and complete each other. Fisher (2009) proposes that critical thinking is ability to explain what an individual being thought. To learn how to think critically involves some abilities such as: to learn how to ask, when did to ask, what did the question, how did its reasoning, when did the reasoning use, and what kind of method did he use. Other writer defines mathematical critical thinking as reasonable reflective thinking and focussed on trusted activities, or as process of thinking which its goal to derive reasonable 


\section{Jurnal Riset Pendidikan Matematika, 5 (2), 2018 - 224}

Euis Eti Rohaeti, Dadang Koswara

conclusion concerning something of truthfulness correctly (Ismaimuza, 2010). Similar to that definition, Noer (2009) proposes that mathematical critical thiking is process deriving a conclusion about what should be trusted and be done. Further, Ennis (Costa, 1985) details indicator of critical thinking into five main groups such as: to give simple explanation, to build basic skill, to conclude, to clarify in depth and to manage strategy.

The meaning of critical thinking is also presented by other writer as well, namely Glazer (2004) states that critical thinking involves three activities such as: (a) to prove: ability to derive conclussion deductively based on prior learned theorms, (b) to generalize: ability to generate pattern in wider condition; c) problem solving: ability to identify known data, asked data and to examine sufficiency components for solving the problem, to compile mathematical model and to solve it, and to check the truth of the solution.

Other detailed indicator of critical thinking is proposed by Bayer (Hassoubah, 2004) those are: (a) to determine credibility of resources, (b) to differenciate relevant and unrelevant data, (c) to differenciate a fact and an evaluation, (d) to identify and to evaluate unwritten asumption, (e) to identify happened bias, (f) to identify viewpoint, and (g) to evaluate offered proof for supporting confession. Similar to Bayer's statement, Ellis (Rosyada, 2004) proposes that critical thinking involves some abilities such as: (a) able to differenciate between fact and demanded value, (b) able to differenciate among information, reason, and relevant and unrelevant demand, (c) able to determine accurate facts, (d) able to determine credible resources, (e) able to identify demand and ambiquistic argument, (e) able to identify unwritten asumption, (f) able to detect bias, (g) able to identify fallacious logic, (h) able to identify unconsistent logic, and (i) able to determine strongest argument or demand.

An expert in critical thinking, Nickerson (Schafersman, 1991) proposes similar traits to Bayer's indicators of critical thinking ability as follow: to use facts proviciently and trustly; to organize and to articulate thought clearly, logically, and reasonable; to differenciate valid and invalid conclussion; to identify the sufficiency of data; to understand the difference between reasoning and rationalization; to try to anticipate possible effect from various activities; to understand ideas fit to level of confidence; to notice similarity and analogy deeply; able to learn independently and having interest continously in learning; to carry out problem solving technique into other learned domain; able to represent an informal problem into formal ways; to ask about a viewpoint and its implication; to be sensitive toward the difference between validity and intensity of a belief and of personal belief; to realize limited personal understanding, and many facts should be explained with non inquiry attitude; to recognize posibility of fallacious and bias of opinion, and to recognize facts according to own opinion.

The afformention arguments on critical thinking ilustrates that critical thinking task is a heavy, complex, and difficult high order mathematics thinking task. That statement implies that for excecuting mathematical critical thinking task student should have strong soft-skill and interest in mathematics so that the student want and able to solve when he faced mathematical critical thinking task. One of the mathematical soft-skill above among other is mathematical resiliency.

Some experts define resiliency term almost similar. First, Block (Klohnen, 1996) defines ego-resiliency as general ability which involves high and flexible self acclimatization toward internal or external pressure. Then, some writters modify that definition into mathematical situation. Bernard (2004) proposes that resiliency is ability of a person to arise from unsatishfying situation when realized a pressure. That ability relates to individual development and livelihood for becoming better condition from the condition before realized pressure; those ability can be observed from individual competence such as social competence, problem solving skill, autonomy, and sense of purpose.

Dweck (Sumarmo, 2015) proposes that mathematical resiliency involves persistent attitude when faced difficulty, able and having willingness to learn and to work colaboratively in peer group, having ability to speak and to express mathematical understanding, and to master mathematics learning theory. Similar definition is proposed by Newman (Sumarmo, 2015) that mathematical resiliency is having high quality attitude in learning mahematics such as: self confidence on own success through hard work, performed persistent to face difficulties, has willingness to discuss, to reflect, and to research. Then, Kooken, et al. (Sumarmo, 2015) conceptualizes mathematical resiliency as adaptive and positive attitude toward mathematics for still to continue to learn mathematics even confront difficulties. From those arguments, Sumarmo 


\section{Jurnal Riset Pendidikan Matematika, 5 (2), 2018 - 225}

Euis Eti Rohaeti, Dadang Koswara

(2015) implies that students who possess strong mathematical resiliency would have mathematical abilities not only for answering examination question but the most important thing are that students mastere those mathematics abilities for solving problem in other dicipline and students had strong desire to apply those mathematics abilities whenever they needed.

Those afformention argument implies that mathematical resiliency is personal behavior for being resistent and uneasy give up when facing difficluties in learning mathematics, and try to learn and adapt to fit that condition and then to arise to become better self confidence. JohnstonWilder and Lee (Sumarmo, 2015) proposes four components of mathematical resiliency, namely: (a) believe that brain ability could be grew; (b) personal understanding toward the value of mathematics, (c) to understand the way to work on mathematics, (d) awareness for supporting from peer group, adult people, internet, ICT, and others.

Curriculum 2013 of Indonesia suggests that mathematical hard-skill such as mathematical critical thinking ability and mathematical soft-skill such as mathematical resilency should be developed simoultaneously. Moreover, Polya and Ashton (1973), states that teacher's role not only to deliver information but the most important things are to position as students, to understand what students think, to help students to think, and to learn to construct their knowledge. Those opinion describes constructivism philoshopy traits namely: (a) student active learning, (b) information is related to previous students' knowledge in order to form meaningfull and more complex knowledge; (c) learning activities are oriented to investigation and invention.

Teaching-learning approach which in line with suggestion of Curriculum 2013, and Polya's statement on teacher's role, among other is scientific approach. Nur (Ibrahim, 2011), states that scientific approach is an approach for obtaining knowledge through two activities that are reasoning and observing. Like that, Sudarwan (2013) clarifies more detailed activities in scientific approach: observation, reasoning, inventing, validation, and explanation about the truth. Similar to Sudarwan's clarification, Hosnan (2014) proposes that scientific approach is an approach which designed such a way so that student constructs concepts, rules, or principles actively through some activities, namely: observation, formulating problem and hypothesis, collecting data by various strategies, analyzing data, concluding and communicating the invented concepts, rules, and or principles.

Then, Kurniasih and Sani (2013) clarify student's activities in each phase of scientific approach in detailed. In observation phase, student invents relation between an analyzed object to teacher's learning material. Then in questioning phase, student exercises to pose questions and this activity is expected will improve student's curiousity. In colaboration phase, student explain his ideas to each other member, so that student will obtain better mathematical understanding, and improve student's good attitude such as: persistent, trusted, polite, respect to other person's opinion. In the next, experimenting phase, student carries out his attained knowlegde from prior phases, and it will improve student' abilities on comunicating, collecting data, learning habit, and learn all the time. Further phase, that is associating, student processes all collected information, and relates it each other, this activities will improve student's excelent attitudes such as honest, accurate, dicipline, consistent, hard work, and also will improve student's abilities as well those are to execute procedure, to think inductively and deductively. In the last phase, student presents all of had done orally or writtenly, and this activiteswill improve student's ability to speak well and correctly.

Some studies which carried out scientific approach (Atsnan \& Gazali, 2013, Efriana, 2014) reported that student performed active learning in all four phases such as to invent mathematical concept, to collect and analize data and then to solve the problem together. Besides that, student demonstrated good attitude and obtained better mathematics learning outcomes. Septiani (2016) by using scientific approach reported that vocational student obtained fairly good grade on mathematical understanding and communiction, but there were no difference on students' self regulated learning in both classess. Nevertheles, Kusnadi (2016) reported that students getting treatment with scientific approach obtained better grade on mathematical critical thinking than the grade of students taught by conventional teaching, but students' grades were still at low level. Seemingly almost students realized difficulties on solving mathematical critical thinking problems.

Other recent study (Carli, 2017) reported that there was no different students' grades on mathematical resiliency between students getting treatment with problem posing approach and with conventional teaching, and the student's grade 
was at medium level. A number of studies with senior and junior high students (Ambarwati, 2011; Fatmawati, 2014, Ismaimuza, 2010; Noer, 2010; Kurniati, Kusumah, Sabandar, Herman, 2015; Kusnadi, 2016; Sinurat, 2014, Sumarmo, Hidayat, Zulkarnaen, Hamidah, Sariningsih, 2012; Tamsil, 2015; Widyaningtiyas, 2015) reported that on mathematical critical thinking students getting treament with innovative approaches obtained at low to medium grade level. Similar to Kusnadi's finding, in those studies mathematical critical thinking is difficult task for many yunior and senior high school students.

The afforementioned arguments, motivate researcher to carry out a study for improving students' mathematical critical thinking ability and mathematical resiliency by using scientific approach. Therefor, the purpose of this study was to describe the role of scientific approach on students' mathematical critical thinking and resiliency.

\section{METODE}

This study is a pre test-post test experimental contorl group design which having a goal to analyze the role of scienctific approach on students' mathematical critical thinking ability and mathematical resiliency. The study involved 66 eleventh grade students. Data collection was conducted through a mathematical critical thinking test, a mathematical resiliency questionnaire, and a perception on scientific approach questionnaire. The mathematical critical thinking ability test consisted of 4 items, The characteristic mathematical critical thinking ability as follow: reliability test was $r=0.75$; discriminat index $(b)$ was $0.30 \leq b \leq 0.60$, and difficulty index $(a)$ was $0.30 \leq a \leq 0.70$. In the following, we attached sample items of mathematical critical thinking test, and sample items of mathematical resiliency questionnaire.

\section{Sample Item of Mathematical Critical Thinking Test}

(To examine the truth of statement accompanied with explanation)

Suppose a reporter informed: $90 \%$ out of spectator in Siliwangi Stadium having an age between 25 and 55 years old.

a. Almost spectators in Siliwangi Stadium were adult. Examine the truth of that statement, and explain your reason.

b. There are no children watch in Siliwangi Stadium. Is the conclussion true? Why?

\section{Sample Item of Mathematical Resiliency Questionnaire}

Note: QO: qiuet often; O: often; ST: some times; S: Seldom; QS: qiuet seldom

\begin{tabular}{|c|c|c|c|c|c|}
\hline No. & Statement & $\mathrm{QO}$ & $\mathrm{O}$ & ST & $S$ \\
\hline 1. & $\begin{array}{l}\text { Be confident able to } \\
\text { practice to pose } \\
\text { question on ratio } \\
\text { accompanied with } \\
\text { relevant reason even } \\
\text { it takes a long time } \\
(+)\end{array}$ & & & & \\
\hline 2. & $\begin{array}{l}\text { To feel bothered to } \\
\text { be asked help when a } \\
\text { friend revealed a } \\
\text { difficulty on solving } \\
\text { ratio problem (-) }\end{array}$ & & & & \\
\hline 3. & $\begin{array}{l}\text { Unafraid to try a new } \\
\text { strategy for solving } \\
\text { ratio problem even } \\
\text { having a fail risk. }(+)\end{array}$ & & & & \\
\hline 4. & $\begin{array}{l}\text { To try to pose } \\
\text { different question } \\
\text { from a series of given } \\
\text { mathematics } \\
\text { information (+) }\end{array}$ & & & & \\
\hline 5. & $\begin{array}{l}\text { To feel learning } \\
\text { spirit decreased after } \\
\text { failed in checking the } \\
\text { truth of statement } \\
\text { about ratio(-) }\end{array}$ & & & & \\
\hline 6. & $\begin{array}{l}\text { Hopeless when failed } \\
\text { to explain resolving } \\
\text { applying ratio } \\
\text { concept to a friend (-) }\end{array}$ & & & & \\
\hline
\end{tabular}

\section{RESULTS AND DISCUSSION}

The results of mathematical critical thinking ability, mathematical resiliency in scientific approach class and conventional class presented in Table 1. From Table 1, in pre-test it found that there was no difference grades of mathematical critical thinking ability of students in both teaching approaches, and the grades were at very low level (less than $10 \%$ out of ideal score). Nevertheles, after learning process, on mathematical critical thinking ability and its gain, students getting treatment whith scientific approach attained better score $(61.85 \%$ out of ideal score, $\mathrm{N}$-Gain $=0.59)$ than the score of students taught by conventional teaching $(40.41 \%$ out of ideal score, $\mathrm{N}-\mathrm{Gain}=0.37$ ). Those findings were similar to a number previous studies such as Ambarwati, (2011), Fatmawati (2014), Ismaimuza (2010), Jayadipura (2014), Kusnadi, (2016), Rohaeti (2008), Sumarmo et al (2012), Sinurat (2014), Tamsil (2016), and Widyaningtiyas, 2015) on mathematical critical 
thinking ability, students getting treatment with various innovative teaching obtained better grades than that of students taught by conventional teaching. But, almost the students' grades on mathematical critical thinking ability were still at low-medium level. But on mathematical resiliency, there was no difference students' grades of mathematical resiliency in both teaching approaches, and those grades were at medium level. Similar finding was reported by Carli (2017) that there was no difference students' grades on mathematical resiliency between students getting treatment with problem posing approach and students taught by conventioanl teaching. Testing hypothesis of those data was attached in Tabel 2. Like that, some studies such as of Jayadipura (2014), Sinurat (2014) reported similar finding that there were no difference on students' score of mathematical disposition and their score were at medium level.

Further analysis, was concerning association between mathematical critical thinking ability and mathematical resiliency. That association was analyzed by using contigency table such as in Table 3 and by using $\chi^{2}$ testing . The analysis obtained value $\chi^{2}=5.738^{\mathrm{a}}$ and sig. $(2$ tailed) is $0.220>0.05$ ). This was mean that there was no association between mathematical critical thinking ability and mathematical resiliency.

Table 1. Description of Students' Mathematical Critical Thinking Ability, Mathematical Resiliency In both Teaching Approaches

\begin{tabular}{cccccccccc}
\hline \multirow{2}{*}{ Variables } & \multirow{2}{*}{ Stat } & \multicolumn{4}{c}{ Scientific Approach } & \multicolumn{5}{c}{ Conventional Teaching } \\
\cline { 3 - 11 } MCTA & & Pre-Test & Post-Test & N Gain & n & Pre-Test & Post-Test & N Gain & n \\
& $\bar{X}$ & 2.47 & 21.03 & 0.59 & & 2.44 & 13.74 & 0.37 & \\
& $\%$ & 7.26 & 61.85 & & 32 & 7.18 & 40.41 & & 34 \\
& SD & 2.17 & 7.83 & 0.24 & & 1.67 & 8.87 & 0.27 & \\
\hline \multirow{2}{*}{ MR } & $\bar{X}$ & & 132 & & & & 133 & & \\
& $\%$ & - & 66 & - & 32 & - & 66.50 & - & 34 \\
& SD & & 10.00 & & & & 9.79 & & \\
\hline
\end{tabular}

Note:

MCTA: Mathematical Critical Thinking Ability

MR: Mathematical Resiliency

Ideal Score: 34

Ideal Score: 200

Table 2. Testing Hypothesis of Mean Difference of Mathematical Critical Thinking Ability, and Mathematical Resiliency on Both Teaching Approaches

\begin{tabular}{|c|c|c|c|c|c|c|c|}
\hline Variables & $\begin{array}{l}\text { Teaching } \\
\text { Approach }\end{array}$ & $\bar{x}$ & SD & $\mathrm{N}$ & $\begin{array}{l}\text { Sig (2- } \\
\text { tailed). }\end{array}$ & $\begin{array}{l}\text { Sig (1- } \\
\text { tailed). }\end{array}$ & Interpretation \\
\hline MCTA & $\begin{array}{l}\text { SA } \\
\text { CT }\end{array}$ & $\begin{array}{l}21.03 \\
13.74\end{array}$ & $\begin{array}{l}7.83 \\
8.87\end{array}$ & $\begin{array}{l}32 \\
34\end{array}$ & .000 & $.000<.05$ & MCTA $_{\mathrm{sa}}>\mathrm{MCTA}_{\mathrm{ct}}$ \\
\hline $\begin{array}{l}\text { N-Gain } \\
\text { MCTA }\end{array}$ & $\begin{array}{l}\text { SA } \\
\text { CT }\end{array}$ & $\begin{array}{l}0.59 \\
0.37\end{array}$ & $\begin{array}{l}0.24 \\
0.27\end{array}$ & $\begin{array}{l}32 \\
34\end{array}$ & .000 & $.000<.05$ & $\begin{array}{l}\text { N-Gain MCTA } \text { SA }_{\text {> }}> \\
\text { N-Gain MCTA }_{C T}\end{array}$ \\
\hline MR & $\begin{array}{l}\text { SA } \\
\text { CT }\end{array}$ & $\begin{array}{l}132 \\
133\end{array}$ & $\begin{array}{c}10 \\
9,79\end{array}$ & $\begin{array}{l}32 \\
34\end{array}$ & .782 & $.396>.05$ & $\begin{array}{l}\text { No difference of MR } \\
\text { and } M R_{C T}\end{array}$ \\
\hline
\end{tabular}

Note:

MCTA: Mathematical Critical Thinking Ability

MR : Mathematical Resiliency

SA : Scientific Approach

CT : Conventional Teaching

Ideal score: 34

Ideal score MR: 200

Table 3. Contigency Table of Mathematical Critical Thinking Ability And Mathematical Resiliency in Scientific Approach Class

\begin{tabular}{|c|c|c|c|c|}
\hline $\begin{array}{ll}\text { MCTA } & \text { MR } \\
\end{array}$ & High & Medium & Low & Total \\
\hline High & 0 & 14 & 1 & 15 \\
\hline Medium & 0 & 7 & 0 & 7 \\
\hline Low & 2 & 8 & 0 & 10 \\
\hline Total & 2 & 29 & 1 & 32 \\
\hline
\end{tabular}


This findings was similar to other previous studies (Sinurat, 2014, Sumarmo, et al, 2012, Widyaningtiyas, 2015) that there were no association between mathematical critical thinking ability with various affective mathematics learning outcomes. But, those findings was different with some other studies (Jayadipura, 2014, Tamsil, 2015) that there were association between mathematical critical thinking ability with various affective mathematics learning outcomes. Those findings indicated that there were incosistent findings on the existency of association between mathematical critical thinking ability and various affective mathematics learning outcomes.

Students' score on each item mathematical critical thinking test is attached in Table 4. In both teaching approach, students realized difficulties in solving almost item of mathematical critical thinking problems. Seemingly, mathematical critical thinking tasks were difficult mathematical processess for yunior high school students. The low students' score on mathematical critical thinking task, might be caused of some factors among them is students do not master yet prerequisite of mathematics content. As an implication of that estimation, it is suggested before teacher is going to teach a new mathematics content, the lesson should be preceded by examining students' mastering the prerequisite of new mathematics content will be learned. When students have already master that prerequisite teacher can carry on the lesson. Whereas, students do not master it yet teacher should carry out remedial teaching. In fact, that suggestion is line with findings of some studies (Ismaimuza, 2010; Kurniawati, Kusumah, Sumarmo, \& Sabandar, 2016; Pujiastuti, Kusumah, Sumarmo, \& Dahlan, 2014; Setiawati, 2014; Widyaningtiyas, 2015) that prior mathematics ability (prerequisite content will be learned) took a role on improving mathematics abilities. That statement is supported by findings the higher student' grade on prior mathematics ability students obtained higher score mathematics abilities as well.

Besides it, this study reported that students expressed high perception on scientific teaching approach and they performed more active learning in all four phases of scientific approach than in conventional teaching such as in the following figures (Figure 1, Figure 2, Figure 3, Figure 4, Figure 5, and Figure 6).
Table 4. Mean Score of Each Item of Mathematical Critical Thinking Ability of Students in The Both Teaching Approaches

\begin{tabular}{cccccc}
\hline Teaching & Desc. & Item & Item & Item & Item \\
Approach & Stat. & 1 & 2 & 3 & 4 \\
\hline Scientific & $\begin{array}{c}\text { Ideal } \\
\text { Score }\end{array}$ & 8 & 10 & 6 & 10 \\
& $\begin{array}{c}\text { Mean } \\
\% \text { of } \\
\text { ideal }\end{array}$ & 3.60 & 5.20 & 3.72 & 3.50 \\
& $\begin{array}{c}\text { score } \\
\text { Mean } \\
\% \text { of }\end{array}$ & 2.64 & 3.90 & 2.04 & 3.30 \\
Conventional & & & & \\
& $\begin{array}{c}\text { ideal } \\
\text { score }\end{array}$ & 33 & 39 & 34 & 33 \\
\hline
\end{tabular}

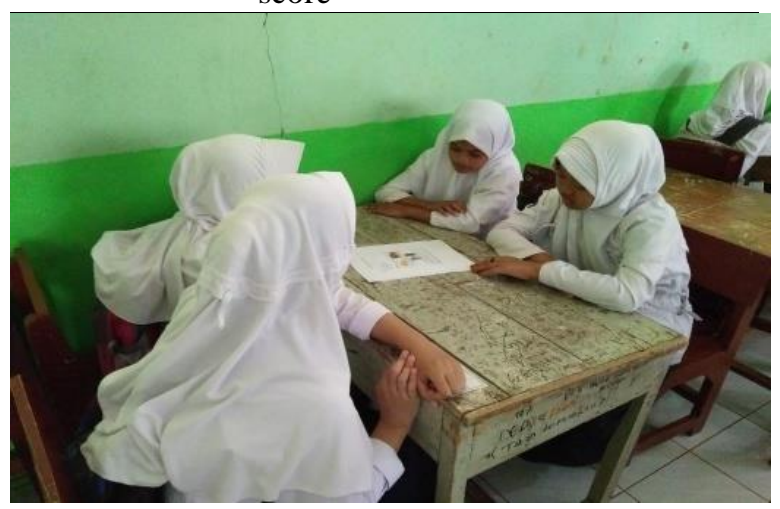

Figure 1. Students’ Activityy in Observing

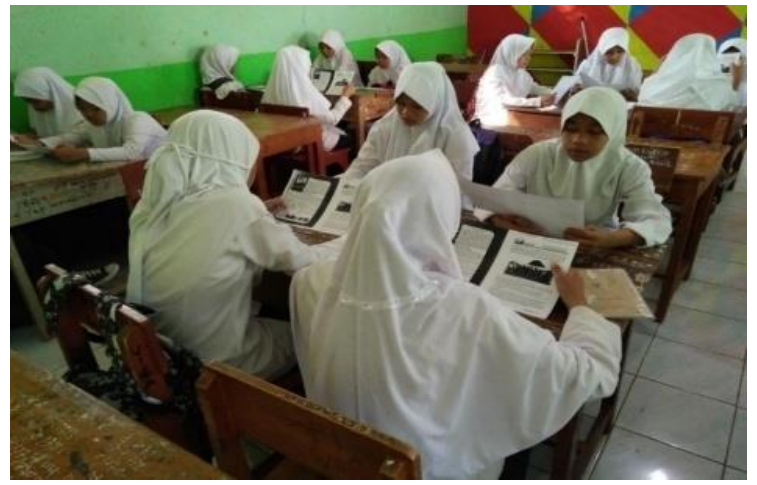

Figure 2. Students' Activity in Questioning Phase

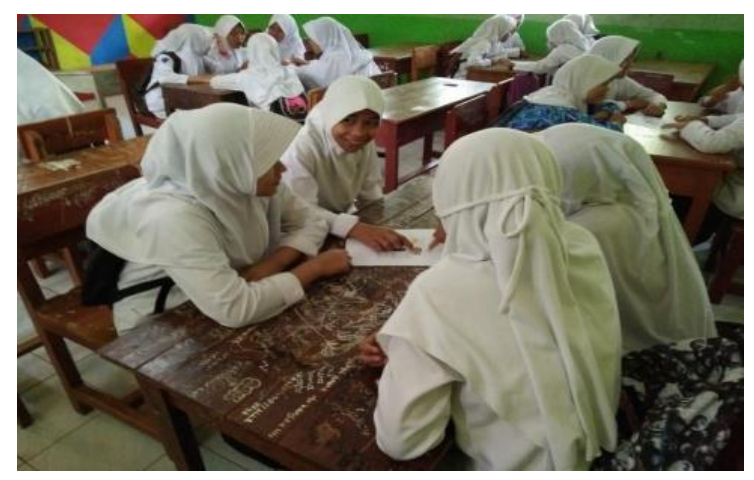

Figure 3. Students' Activity in Association Phase 
Jurnal Riset Pendidikan Matematika, 5 (2), 2018 - 229

Euis Eti Rohaeti, Dadang Koswara

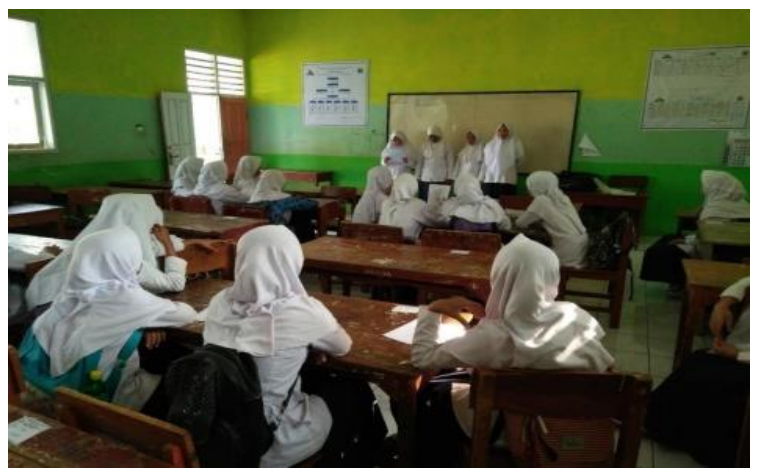

Figure 4. Students' Activity in Communication Phase

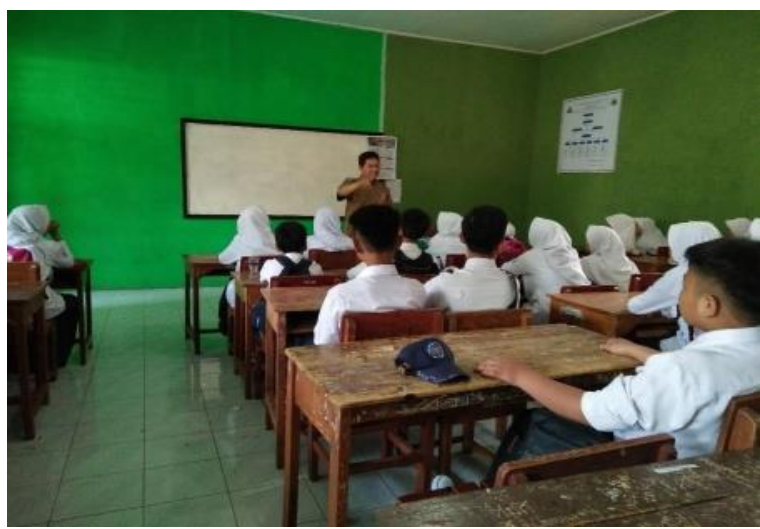

Figure 5. Teacher's Explanation in Conventional Class

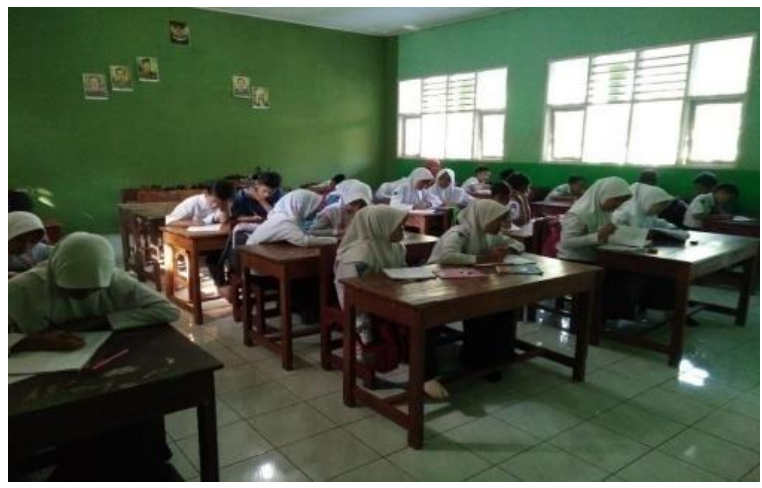

Figure 6. Students' Activity When Doing

Excercises in Conventional Class

Finding of this study, that students performed positive perception on scientific teaching approach was similar to findings of some recent studies namely: on problem posing approach (Carli, 2017), on inductive-deductive approach (Eriska, 2017), on problem based learning (Johanto, 2017), on scientific approach (Kusnadi, 2016, Mulyani, 2017), on generative approach (Sumarni \& Sumarmo, 2017), on contextual teaching (Ruhiyat \& Sugandi, 2017), on model eliciting activities (Suharyati, 2017).

\section{CONCLUSION}

Based on findings and discussion can be conclude that scientific approach took better role than conventional teaching on improving students' mathematical critical thinking ability and its gain, but not on students' mathematical resiliency. However the students' mathematical critical thinking ability score was still at lowmedium level and on mathematical resiliency students' score was at medium level. Beside it, students on both teaching approaches realized difficulties in solving mathematical critical thinking ability problems. The other conclusion was students peformed high perception on scientific approach and they demonstrated active learning in all four phases of scientific approach and there was no association between mathematical critical thinking ability and mathematical resiliency.

Based on the conclusion and discussion the study proposed some suggestion. The students' score on mathematical critical thinking ability in both class were at low level. Mathematical critical thinking is classified as high order thinking (HOT) in mathematics. For obtaining mathematical critical thinking task or other HOT mathematics students should master prerequisite of mathematical process and content of mathematical critical thinking ability. So, before teacher were going to explain a new mathematics topic or content or to conduct study on mathematical HOT ability, it was suggested to examine students' abilities of its prerequisite firstly. Besides it, students should be motivated to select and to solve more exercises by theirselfes on mathematical critical thinking task or other mathematical HOT task. Further,in order students attained meaningfull mathematical critical thinking ability, it was suggested students asked to write the formulas and rules which used on each step in solving the problems as well.

To improve better students' mathematical resiliency, it was suggested four ways as follow: be aware of students to the importance of having mathematical resiliency; teacher should perform having behavior as wished in mathematical resiliency; students should be accustomized having behavior as wished in mathematical resiliency; and teacher should carry out integrated and continous mathematics teaching process.

\section{REFERENCES}

Ambarwati, D. (2011). Mengembangkan kemampuan berpikir kritis dan kreatif melalui pendekatan pembelajaran 


\section{Jurnal Riset Pendidikan Matematika, 5 (2), 2018 - 230}

Euis Eti Rohaeti, Dadang Koswara

langsung dan tak langsung. Thesis. Universitas Pendidikan Indonesia, Bandung.

Atsnan, M. F., \& Gazali, R.Y. (2013). Penerapan pendekatan scientific dalam pembelajaran matematika SMP kelas VII materi bilangan (pecahan). Prosiding Seminar Nasional Matematika dan Pendidikan Matematika, FMIPA UNY.

Bernard, B. (2004). Resiliency: What we have learned. San Fransisco, CA: WestEd.

Fisher, R. (1995). Thinking children to think. Cheltenham, United Kingdom: Thornes.

Carli, C. (2017). Meningkatkan kemampuan berpikir reflektif dan berpikir kreatif serta resiliensi matematik siswa SMA dengan menggunakan pendekatan problemposing. Thesis, STKIP Siliwangi, Bandung.

Costa, A. L. (1985). Developing minds: A resource book for teaching thinking association for supervision and curriculum development. Alexandria, VA: Association for Supervision and Curriculum Development

Efriana, F. (2014). Penerapan pendekatan scientific untuk meningkatkan hasil belajar siswa kelas VII MTSN Palu Barat pada materi keliling dan luas daerah layanglayang. Jurnal Elektronik Pendidikan Matematika Tadulako, 1(2), 170-181

Eriska, K. (2017). Meningkatkan kemampuan komunikasi dan penalaran serta disposisi matematik siswa madrasah alyah dengan menggunakan pendekatan induktifdeduktif. Thesis. STKIP Siliwangi, Bandung.

Fatmawati, H. (2014). Analisis berpikir kritis siswa dalam pemecahan masalah matematika berdasarkan Polya pada pokok bahasan persamaan kuadrat. Jurnal Elektronik Pembelajaran Matematika, 2(9), 899-910.

Fisher, A. (2009). Berpikir kritis: Sebuah pengantar. Jakarta: Erlangga.

Glazer, E. (2004). Technology enhanced learning environment that are conductive of critical thinking in mathematics. Retrieved from http://www.lonestar.texas.net/scifert/crit2.html 6 Desember 2009.
Hassoubah, Z. I. (2004). Developing creative \& critical thinking skills. Bandung, Indonesia: Yayasan Nuansa Cendekia.

Hosnan, M. (2014). Pendekatan saintifik dan kontekstual dalam pembelajaran abad 21 . Bogor: Ghalia Indonesia.

Ibrahim, I. (2011). Pengembangan kemampuan berpikir kritis dan kreatif matematis siswa melalui pembelajaran berbasis-masalah yang menghadirkan kecerdasan emosional. Prosiding Seminar Nasional Matematika dan Pendidikan Matematika FMIPA UNY.

Ismaimuza, D. (2010). Kemampuan berpikir kritis dan kreatif matematik siswa SMP melalui pembelajaran berbasis masalah dengan strategi konflik kognitif. Disertation. Universitas Pendidikan Indonesia, Bandung.

Jayadipura, Y. (2014). Mengembangkan kemampuan berpikir kritis dan kreatif matematis serta kemandirian belajar siswa SMA melalui pembelajaran kontekstual. Thesis. STKIP Siliwangi, Bandung.

Johanto, T. (2017). Meningkatkan kemampuan komunikasi dan pemecahan masalah matematik serta kepercayaan diri siswa SMA melalui pendekatan problem-based learning. Thesis. STKIP Siliwangi, Bandung.

Klohnen E. C. (1996). Conceptual analysis and measurement of the construct of egoresiliency. Journal of Personality and Social Psychology, 70, 1067-1079.

Kurniasih, I., \& Sani, B. (2014). Implementasi Kurikulum 2013 konsep dan penerapan. Surabaya: Kata Pena.

Kurniati, K., Kusumah, Y. S., Sabandar, Y., \& Herman, T. (2015). Mathematical critical thinking ability through contextual teaching and learning approach. Journal on Mathematics Education (IndoMS$J M E$ ), 6(1), 53-62.

Kurniawati, L., Kusumah, Y. S., Sumarmo, U., \& Sabandar, Y. (2014). Enhancing Students' mathematical intuitive-reflective thinking ability through problem based learning with hypnoteaching mathod. Journal of Education and Practice, 6(36), 130-135.

Kusnadi. A. (2016). Peningkatan komunikasi dan berpikir kritis serta disposisi matematik 
siswa SMK melalui pendekatan saintifik. Thesis. STKIP Siliwangi, Bandung.

Lunenburg, F. C. (2011). Critical thinking and constructivism techniques for improving student achievement. National Forum Teacher Education Journal, 21(3), 1-9.

Mulyani, E. (2017). Meningkatkan kemampuan komunikasi dan berpikir kreatif matematik serta self-confidence siswa SMK melalui pembelajaran saintifik. Thesis. STKIP Siliwangi. Bandung.

Noer, S. H. (2010). Peningkatan kemampuan berpikir kritis, kreatif, dan reflektif (K2R) matematik siswa SMP melalui pembelajaran berbasis masalah. Disertation, Universitas Pendidikan Indonesia, Bandung.

Peter, E. E. (2012). Critical thinking: Essence for teaching mathematics and mathematics problem solving skills. African Journal of Mathematics and Computer Science Research, 5(93), 39-43.

Pertiwi, N. (2011). Pengaruh metode kooperatif strategi the power of two terhadap kemampuan berpikir kritis siswa SMP dalam pembelajaran matematika. Thesis. Universitas Pendidikan Indonesia, Bandung.

Pujiastuti, H., Kusumah, Y. S., Sumarmo, U., \& Dahlan, J. A. (2014). Inquiry co-operation model for enhancing junior high school students' mathematical problem solving ability. International Journal of Contemporary Educational Research, 1(1), 51-60.

Polya, G. M., \& Ashton, A. R. (1973). Inhibition of wheat seedling $5^{\prime}\left(3^{\prime}\right)$-ribonucleotide phosphohydrolase by adenosine 3', 5'cyclic monophosphate. Plant Science Letters, 1(9), 349-357.

Rohaeti, E. E. (2008). Pembelajaran dengan pendekatan eksplorasi untuk mengembangkan kemampuan berpikir kritis dan kreatif matematik siswa sekolah menengah pertama. Disertation. Universitas Pendidikan Indonesia, Bandung.

Rosyada, D. (2004). Paradigma pendidikan demokratis. Jakarta: Primada Media.

Ruhiyat, A., \& Sugandi A. I. (2017). Meningkatkan kemampuan berpikir kreatif dan disposisi matematik siswa SMP dengan menggunakan pendekatan kontekstual. Edusentris: Jurnal Ilmu Pendidikan dan Pengajaran, 3(1), 281289.

Schafersman, S. D. (1991). An introduction to critical thinking. Retrieved from http://www.freeinquiry.com/criticalthinking.html

Setiawati, E. (2014). Mengembangkan kemampuan berpikir logis, kreatif, dan habits of mind matematis melalui pembelajaran berbasis masalah: Eksperimen terhadap siswa madrasah Aliyah. Dissertation, Universitas Pendidikan Indonesia, Bandung.

Septiani, R. S. (2016). Meningkatkan kemampuan pemahaman dan komunikasi matematik serta kemandirian belajar siswa SMK dengan menggunakan pendekatan saintifik. Thesis. STKIP Siliwangi, Bandung.

Sinurat, R. (2014). Meningkatkan kemampuan berpikir kritis dan kreatif serta disposisi matematik siswa SMA melalui pembelajaran kontekstual. Thesis. STKIP Siliwangi, Bandung.

Sudarwan, D. (2013). Menjadi penulis kualitatif. Bandung: Pustaka Setia.

Suharyati. (2017). Meningkatkan kemampuan komunikasi dan penalaran matematik serta kemandirian belajar siswa SMP melalui pendekatan model eliciting activities. Thesis, STKIP Siliwangi, Bandung.

Sumarmo, U., Hidayat, W., Zulkarnaen, R., Hamidah, \& Sariningsih, R. (2012). Kemampuan dan disposisi berpikir logis, kritis, dan kreatif matematis: Eksperimen terhadap Siswa SMA menggunakan pembelajaran berbasis masalah dan strategi think-talk-write. Jurnal Pengajaran MIPA, 17(1), 17-33.

Sumarmo, U. (2015). Resiliensi matematik (Mathematical Resilience). Retrieved from utari-

sumarmo@dosen.stkipsiliwangi.ac.id.

Sumarni, C., \& Sumarmo, U. (2017). Penalaran matematik dan kemandirian belajar: Eksperimen terhadap siswa SMP melalui pembelajaran generatif. Edusentris: Jurnal Ilmu Pendidikan dan Pengajaran, 3(1), 290-299.

Tamsil, S. (2015). Meningkatkan kemampuan berpikir kritis dan kreatif matematik serta 
Jurnal Riset Pendidikan Matematika, 5 (2), 2018 - 232

Euis Eti Rohaeti, Dadang Koswara

kepercayaan diri siswa SMA melalui

masalah terhadap kemampuan dan pembelajaran langsung-tak langsung. Unpublished Thesis Master, STKIP Siliwangi, Bandung.

Widyaningtiyas, R. (2015). Pengaruh disposisi berpikir kritis dan kreatif matematis siswa SMA. Unpublished Disertation Doctoral. Universitas Pendidikan Indonesia, Bandung. 